\title{
THEME AND LYRICISM: TWO CONSIDERATIONS IN THE ISLAMIC WRITING TRADITION MOTIVATING MUSLIM AUTHORS IN NAMING THEIR WORKS
}

\author{
Şener Şahin \\ Bursa Uludă̆ University, Bursa-Turkey \\ senersahin@uludag.edu.tr \\ https://orcid.org/0000-0002-2499-7672
}

\begin{abstract}
The implementation of the saj (rhymed prose) style for the denomination of works is a writing tradition among medieval Muslim intellectuals and a widespread artistic effort that is still extant today. Indeed, thematic restriction has played a role as a motivating factor in the creativity of authors in the classical era in terms of sajc. The objective of this paper is to present the distinctive solidarity between theme and $s a j$ ' that stands out in the book titles of countless Islamic classics by means of a comprehensive examination of book names by Muslim authors between the $3^{\text {rd }}$ and $10^{\text {th }}$ centuries AH. This paper also attempts to identify why scholars could not renounce thematic restrictions and aesthetics based on ornamental sensibility when naming their scientific works.
\end{abstract}

Key Words: Islamic writing tradition, names of works, book title, onomastics, saj`(rhymed prose), aesthetics, embellished prose

Ilahiyat Studies

Volume 11 Number 1 Winter / Spring 2020
p-ISSN: 1309-1786 / e-ISSN: 1309-1719

DOI: $10.12730 / 13091719.2020 .111 .202$

Copyright (C) Bursa İlahiyat Foundation

Received: June 19, 2019

Accepted: January 15, 2020

Published: June 30, 2020

To cite this article: Şahin, Şener. "Theme and Lyricism: Two Considerations in the Islamic Writing Tradition Motivating Muslim Authors in Naming Their Works." Ilabiyat Studies 11, no. 1 (2020): 111-143. https://doi.org/10.12730/13091719.2020.111.202 


\section{Introduction}

Experts in onomastics, ${ }^{1}$ a subdiscipline of linguistics, have often concentrated on the names of persons, places, and regions. Nevertheless, this discipline comprises a scope and flexibility that enables the examination of book titles put to paper in a certain language, region or culture. In particular, the significant amount of variable book titles created by Muslim scholars using a limited word staff as well as the striking artistic effort in the design of these titles are truly worth noting and deserve closer analysis.

Rhymed prose (نَثْر مُسَجَّحع), which initially emerged in works in the $m a q \bar{a} m \bar{a} t$ genre as of the $3^{\text {rd }}$ century $\mathrm{AH}$ and rapidly flourished, is a much examined artistic style. The objective of this study is a comprehensive examination of the theme and form of book titles from various disciplines, particularly in the Arabic language and literature as well as tafsīr, hadīth, history of religions, Sufism, philosophy, botany, zoography, zoology, mineralogy, astrology, astronomy, and numismatics, created by the $s a j$ ' style. The scope of our study covers the titles of works written between the $3^{\text {rd }}$ and $10^{\text {th }}$ centuries AH to follow the evolution and witness the ongoing vivacity of the $\operatorname{saj}^{c}$ style, ${ }^{2}$ which became a writing tradition among medieval Muslim intellectuals. ${ }^{3}$

1 It was Aristotle who identified this linguistic discipline for the first time. In the course of time, dozens of subdisciplines were formed in consideration of the relevant object or concept. Murat and Gülkanat, who describe onomastics as an extensive phenomenon with dynamic structure, indicate that it covers a vast scope, from the names of buses to flowers. See Mualla Murat and Gizem Gülkanat, "Onomastik Bilimi ve Eğitim,” Sosyal Bilimler Dergisi 5, no. 28 (2018), 248, http://dx.doi.org/10.16990/SOBIDER.4485.

2 Geert Jan van Gelder, "Antidotes and Anecdotes: A Literary History of Medicine from 13th-Century Syria," in Wit and Wisdom in Classical Arabic Literature: Leiden Lectures on Arabic Language and Culture, Petra M. Sijpesteijn, James A. Montgomery, and Geert Jan van Gelder (Leiden: Leiden Publications, 2015), 58.

3 According to Devin J. Stewart, saj $^{`}$ in Arabic literature and Arab society dates back to the pre-Islamic period and maintained its importance until the $20^{\text {th }}$ century AD. Indeed, almost all Arabic works made use of this method. See "Sajc in the Qur'ān: Prosody and Structure," Journal of Arabic Literature 21, no. 2 (1990), 101, https://doi.org/10.1163/157006490X00017. According to Shawqi 
The content of this study excludes book titles that consist of a single word, such as آلْبُخَلَاء (The Avaricious) by al-Jāhiz (d. 255/869), that include no artistic or aesthetic aspect of pronunciation regarding the formation of wording regardless of the quality of their content, such as آلَبَيَانُ وَالتَّبَّبينِ by the same author, or that have an extremely long name, such as

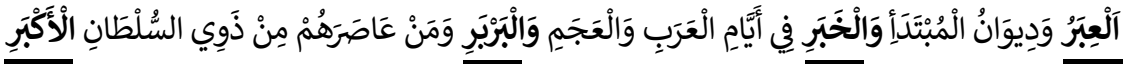

by Ibn Khaldūn (d. 808/1406), which ultimately became known as Muqaddimah. Instead, we concentrate on relatively short or medium-length book titles that skillfully make use of certain techniques and practices of sajc, which is considered "wisdom (albikmah) composed in an expression (al-lafz)" that comprise a lyrical air in pronunciation, consist of the same letters but different words to lead to occasional misreading, and prioritize form and meaning together. The works referred to in this study are interesting, compelling, and even, occasionally, laconic examples with humorous emphasis in terms of pronunciation or meaning.

Pursuant to our methodology, we evaluate book titles in categorical terms and include the name and date of death of the author; thus, we aim to demonstrate how rooted the tradition is. To highlight the theme within a book title, we often make use of bold characters and frames to identify lyrical elements.

Scholars from every discipline have exerted significant effort to create artistic book titles; however, the men of letters are particularly worth noting. While certain book titles are composed through a literary language, they express a certain thesis or assertion. For instance, تَنْوِيرُ الْغَبَشِ فِي فَضْلِ السُودَانِ وَالْحَبَشِ (Illuminating the Darkness: The Virtues of Blacks and Abyssinians) by Ibn al-Jawzī (d. 597/1201) underlines, on the one hand, the principle that "superiority should be sought in piety and not in color of skin," while on the other, it provides a significantly eloquent introduction to the content of the

Dayf, the $s a j$ ' style became a widespread literary taste and practice particularly as of the $10^{\text {th }}$ century AD. Shawqī Dayf, Tārīkh al-adab al-'Arabì (Cairo: Dār alMa'ārif, 1995), IV (al-'Aṣr al-'Abbāsī al-awwal), 573.

4 Dimitri Gutas, "Classical Arabic Wisdom Literature: Nature and Scope," Journal of the American Oriental Society 101, no. 1 (1981), 63, https://doi.org/10.2307 1602164 . 
work. Ibn al-Marzubān al-Muhawwalī (d. 309/921), who complains about the moral degeneration of the men of his time and their disobedience to rules of friendship, uses the title فَضْلُ الْكِكَابِ عَلَى كَثِيِِ مِمَّنْ لَبِسن الثَّيَابَ (The Book of the Superiority of Dogs Over Many of Those Who Wear Clothes).

Some authors are even more successful in echoing the content of their work in their book titles. Al-Suyūțī (d. 911/1505), who is among these meticulous authors, calls his study about the permissibility of

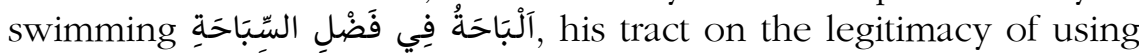

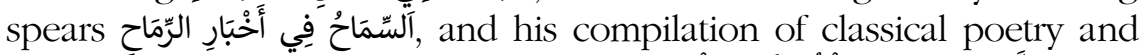

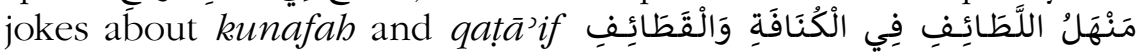
which managed to attract the attention of readers.

\section{Possible Intentions behind the Denomination of Books}

Muslim authors started the writing and registering movement as early as the $2^{\text {nd }}$ century $\mathrm{AH}$ and attached particular importance to the names of their works. It was also a technical requirement to provide a work with a foolproof name. In his definition of the concept of a "book title (آلَعْنْنَانان)" among the eight essential elements within the opening pages of classical works, Kātib Chalabī (d. 1067/1657) writes as follows:

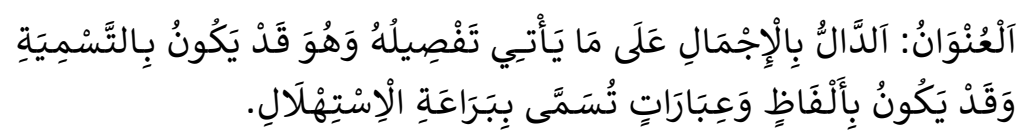

The title is the thing or part that briefly expresses the issues to be eventually detailed. It may be an (ordinary) denomination or be applied through wordings and inscriptions called good beginning. ${ }^{5}$

By the abovementioned good beginning, ${ }^{6}$ Kātib Chalabī understands not only meaning, but also the formal aesthetic ensured

Hājī Khalīfah Mușțafá ibn 'Abd Allāh Kātib Chalabī, Kashf al-ẓunūn 'an asāmī lkutub wa-l-funūn, ed. M. Şerefeddin Yaltkaya and Kilisli Rifat Bilge (Baghdad: Maktabat al-Muthanná, 1941), I, 38.

6 Barā'at al-istiblāl, which is used in the sense of "good beginning" in verse or prose, is examined in classical references under the term busn al-ibtid $\bar{a}$. This style, which ensures an impressive beginning to the qașidah of a poet, the prose of a writer and the correspondences of a scribe, has been in use since earlier periods. See, for example, Abū l-`Abbās Shihāb al-Dīn Aḥmad ibn 'Alī al- 
by saj. Indeed, an attentive examination of bibliographical and biobibliographical works, particularly Kashf al-zunūn, reveals how Muslim authors made use of "denomination" as an effective instrument to attract readers' attention to the book because they would duly benefit from the work. In other words, the essential objectives of classical authors in the creation of the names of their works are extraordinariness to the degree of astonishment, noticeability to the degree of intensity, and artistry to the degree of confusion in terms of syntax.

In our opinion, there are understandable reasons why Muslim authors since the early days have given interesting names to their works. A laconic name that appropriately expresses the content and wish was an incontestable factor in providing the author with popularity. Accordingly, many authors tried to attach their nicknames and epithets to the names of their books in a phonetically aesthetic manner. For instance, the frequently referenced work by Abū 1-Faraj al-Isfahānī (d. 420/1029) is often mentioned together with the name of its author and became known as "الَأَغَانِي لِلِِْصْفَهَانِيَ". The same

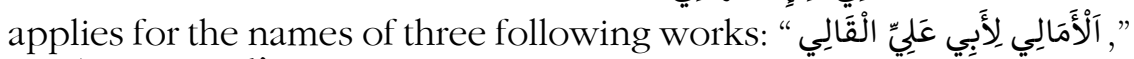

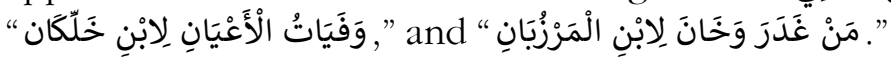

In addition to their noble goal of "disseminating knowledge," the authors also proved their mastery and experience in the Arabic language in the eyes of readers through the extraordinary names of their works. Furthermore, a successful "denomination" meant a higher number of qualified readers and therefore higher commercial "earnings."

The saj ${ }^{c}$ style $^{7}$ has often been employed in the enigmatic expressions of soothsayers, oratories, moving counsels such as

Qalqashandī, Subḥ al-a'shá fì șinā'at al-inshā', ed. Muhammad Ḥusayn Shams al-Dīn (Beirut: Dār al-Kutub al-Ilmiyyah, 1987), I, 47; Abū 1-Ḥasan 'Alī ibn Muḥammad ibn 'Alī al-Sayyid al-Sharīf al-Jurjānī, Kitāb al-ta'rīfāt, ed. Ibrāhīm alAbyārī (Beirut: Dār al-Kitāb al-'Arabīi, 1985), 63; Abū l-Baqā’ Ayyūb ibn Mūsá alHusaynī al-Kafawī, Al-kulliyyāt: Mu'jam fì l-mușțalaḥāt wa-l-furūq allughawiyyah, ed. 'Adnān Darwīsh and Muḥammad al-Miṣrī, 2 ${ }^{\text {nd }}$ ed. (Beirut: Mu’assasat al-Risālah, 1998), 364.

$7 \quad$ Van Gelder, Classical Arabic Literature: A Library of Arabic Literature Anthology (New York \& London: New York University Press, 2013), 110. 
testaments, gnomical sayings, influential sayings such as maxims and parables, as well as religious ritual expressions since the Jāhiliyyah and early Islamic period. On some occasions, Muslim scholars benefited from $s a j^{c}$ to ensure the formal attractiveness of their work. Indeed, as is still true today, a simple and unadorned title created pursuant to $s a j$ in those days not only sounded nice but also raised notable curiosity about the content and moved the reader to access the inner pages. In addition, we should bear in mind that a rhymed phrase stylized by a calligrapher is pleasing to the eye. Indeed, book

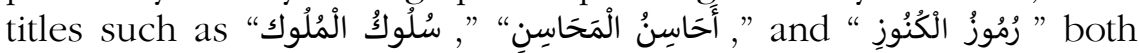
sound and look nice.

Another reasonable ground for the use of puns in book titles is the aesthetic concern arising from the need to add an appropriate

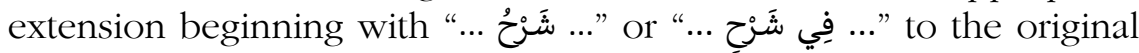
title to name the studies within the age-long tradition of commentaries. The titles are created in this way and for this purpose in countless numbers of commentaries. The name given by al-Suyūṭi

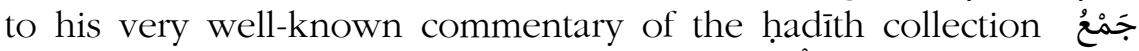
الجَوَامِع is an artistic example: هَمْعُ الْهَوَامِعِ شَرْحُح جَمْعِ الجَوَامِعِ.

In the Muslim world, almost all popular commentaries on al-Șaḥih by the renowned hadìth scholar al-Bukhārì are named pursuant to the same method, and commentators have displayed praiseworthy endeavors to create puns with the name of al-Bukhārī. Here, we present some for clarification:

Ibn Ḥajar al-c'Asqalānī (d. 852/1449)

Al-'Aynī (d. 855/1451)

فَتْحُ الْبَارِي بِشَرْحِح صَحِيحِ الْبُخَارِيِّ

Al-'Ajlūnī (d. 1162/1749)

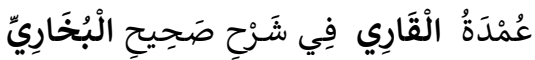

Hasan al-'Idwī al-Ḥamzāwī (d.

1303/1886)
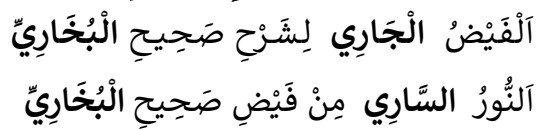

Muḥammad al-Khị̣r al-

Shinqị̄̂i (d.1354/1936)

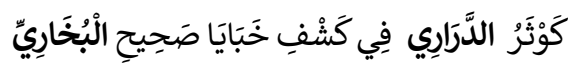

In addition, we should note works that are written to summarize a

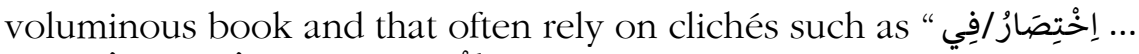
اخْتِصَارِ/مُخْتَصَرُ .... "..." or "... or even those written in relation to a 


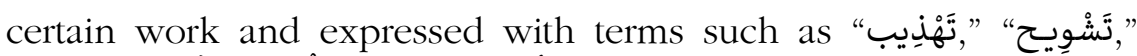

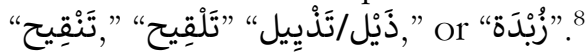

In addition to the foregoing, we should not overlook the influence of Arabic as the common cultural language of the medieval Islamic world. Accordingly, scholars preferred to name their works in Arabic since it was available for ornate prose, even if their work was in fact written in Ottoman Turkish or Persian. For example, the title of a book in Persian that was written and presented to Sultan Bāyezīd II in 895 (1490) by Husayn al-Khaț̣ābī al-Jīlānī, a scholar known for his studies on medicine, astronomy, and mathematics, reads تُحْفَةُ الْحُسَّابِ The same applies for a work written in Turkish (first 222 pages) and Persian and presented to Murād III (1574-1595) by alHazīnī (d. 1002/after 1594), who named it جَوَاهِرُ الَََْْْرَارِ مِنْ أَمْوَاجِ الْبِحَارِ . Interestingly, this work about Ahmad Yasawī and the Yasawiyyah order bears the strong seal of the abovementioned writing tradition in its title even though it is not actually in Arabic. Another example is the Persian work called أَوْرَادُ الََْحْبَابِ وَفُصُوصُ الْدَدَابِ by Kubrawī shaykh Yahyyá ibn Aḥmad al-Bākharzī (d. 736/1335) about mystical etiquette. We can even refer to the name of the Turkish work written in Mecca by the $11^{\text {th }}$-century $\left(17^{\text {th }}\right.$-century AD) Ottoman mathematician 'Alī ibn

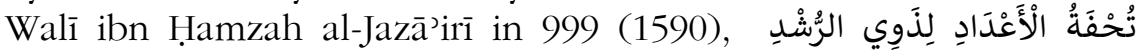

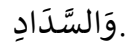

Apparently, the Ottoman scholars followed the same method in their translations from Arabic into Turkish. For instance, a work on

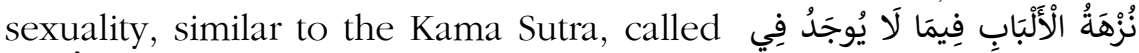
الْكَتَابِ (Excursion of the Hearts in What Cannot Be Found in Any Book)" by the Tunisian qāọī and sex manual writer Shihāb al-Dīn Aḥmad al-Tîfāshì (d. 651/1253), is translated in Turkish by the

${ }^{8}$ See, for example,

Shumaym al-Hillī (d. 601/1205)

Ismāç̄l Rusūkhī Anqarawī (d. 1041/1631)

Aḥmad ibn 'Alī ibn Mas'ūd (d. $8^{\text {th }} / 14^{\text {th }}$ century)

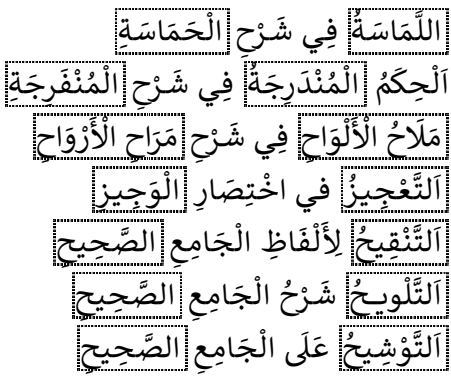

'Abd al-Rahīm al-Mawșilī (d. 1041/1631)

Al-Zarkashī (d. 794/1392)

Mughalțāy ibn Q1lìj (d. 762/1361)

Al-Suyūṭī (d. 911/1505)

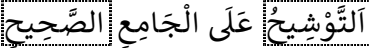


Ottoman Shaykh al-Islām Ibn Kamāl, who preferred an even more fantastic Arabic name for the translation: رُجُوعُ الشَّيْيخ إِلَى صِبَاهِ فِي الْقُوَّة عَلَى الْبَاهِ (The Return of the Old Man to His Youth). Another sex

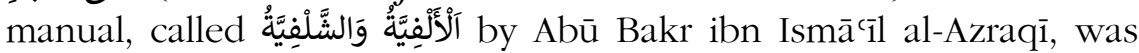
translated by Deli Birader Mehmed Ghazālī (d. 941/1535?) into Turkish with the following Arabic title: رَافِعُ الْهُمُومِ وَدَافِعُ الْغُمُومِ (What Disperses Sorrow and Destroys Sadness).

\section{Diversity within Thematic Restriction}

The most striking point in the book titles by Muslim authors is the impression of restriction with five to ten themes or terms. As shown by numerous examples below, our authors seem to have restricted

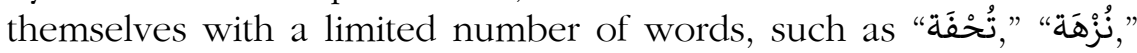

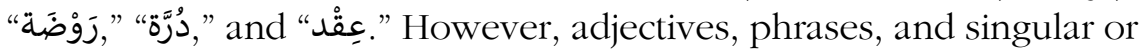
plural forms in the company of these terms created huge diversity and, in a way, revealed the true skill of the author. In other words, even though a medieval author apparently seemed to have constrained himself in a very limited frame, he both stood out and proved his artistry by setting his personal seal on the mentioned clichés. $S a j$ is the most common style for this purpose since it reflects the phonetic aesthetic in the best manner. Indeed, thematic restriction was the main motivation behind the creativity of classical authors in terms of $s a j$ c. Consequently, it is possible to talk about a clear solidarity between theme and $s a j$ ' in the titles of countless Islamic classics.

Presumably, the most appropriate examples of this practice are book titles that consist of names of jewelry and precious stones. Indeed, the association of book titles with certain valuable objects, particularly jewelry, was a common tradition and style among Muslim authors to arouse interest. Pearl was the most prominent of such objects; accordingly, hundreds of famous works were crowned with

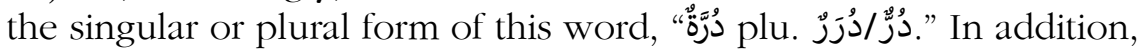
"pearl" was employed together with numerous useful adjectives available for $s a j$ ' techniques, such as "precious, exceptional, unique, well-protected, untouched/virgin, well-ordered/well-arranged, dispersed, chosen/select" or "flawless." Examples in the following list show how a limited theme can be diversified by means of additions to attain a phonetically artistic structure. The elements highlighting saj'are given in boxes: 
Al-Ghazālī (d. 505/1111)

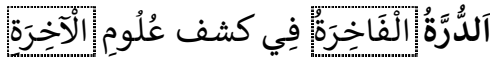

Al-'Azfī (d. 633/1235-36)

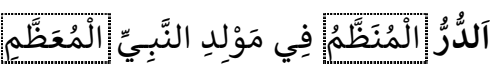

Al-Harīīī (d. 516/1122)

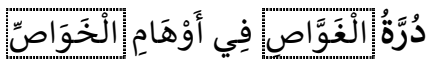

Al-Hamawī (d. 1098/1687)

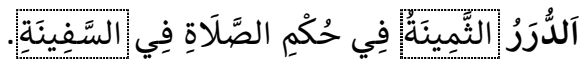

In addition to pearl, many other gems or jewelry adorn the covers

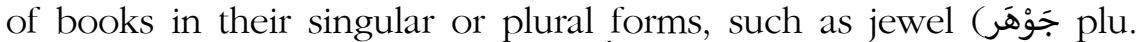

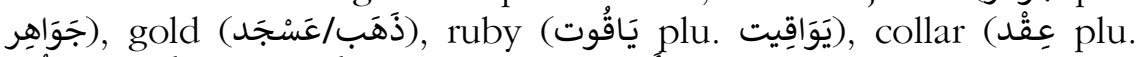

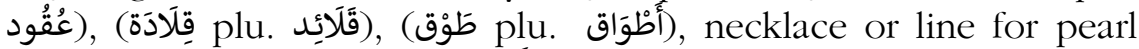

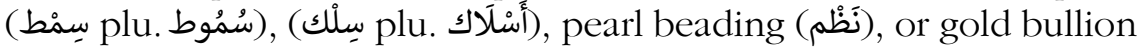

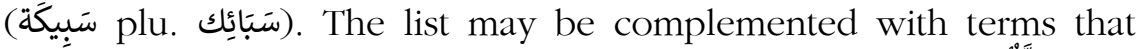

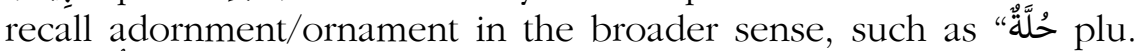

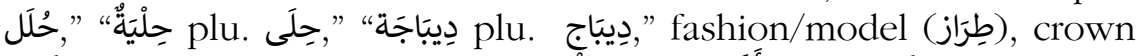

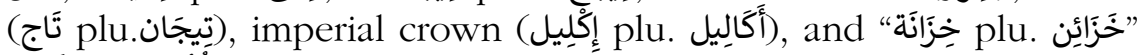
" حَنُْوز

\section{Use of Terminology that Emits Positive Connotations to the Reader}

Authors opted for emotionally positive terminology, such as cheer, pleasure, happiness, and joy, to arouse interest among readers as well as terms of consolation to eliminate sadness and grief. In this context,

9 Here are some interesting examples of the abovementioned terms:

Abū Isḥāq al-Huṣiñ (d. 413/1022)

Abū Manșūr al-Tha'ālibī (d. 429/1038)

Al-Zamakhsharī (d. 538/1144)

Al-Suyūṭī (d. 911/1505)

Abū 'Ubayd al-Bakrī (d. 487/1094)

Ibrāhīm al-Halabī (d. 956/1549)

Fatḥ ibn Khāqān al-Qaysī (d. 529/1135)

Taqī al-Dīn Abū Bakr al-Jarrācīi (d. 833/1478)

Ibn Hạīb al-Halabī (d. 779/1377)

Lisān al-Dīn Ibn al-Khațīb (d. 776/ 1375)

Abū 'Abd Allāh al-Mawwāq (d. 897/1492)

جَمْعُ [الْجَوَاهِِِ فِي الْمُلَحِ وَ النَّوَادِرِا

آَلْيَوَاقِيتُ فِي بَعْضِ الَْمَوَاقِيتِ

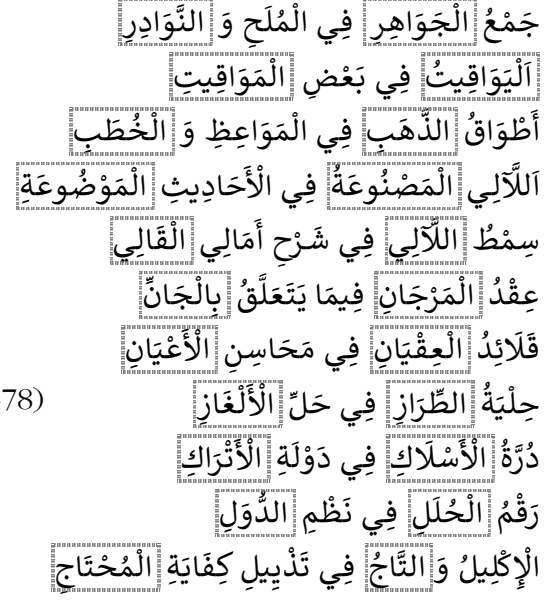

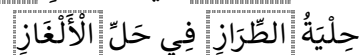

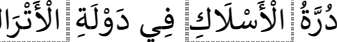

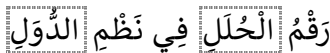

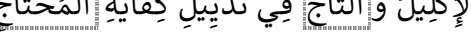


the first group comprises numerous words, and on each occasion, the book title is finalized with striking puns in line with these terms or concepts as their adjective or determinatum. ${ }^{10}$ Popular expressions

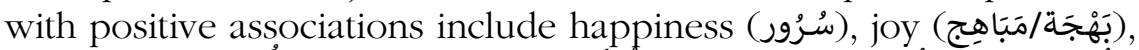

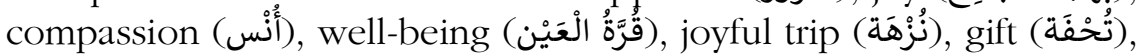
and curio (طُرْفَة). For example, a work about provisions related to obligatory alms (zakāh) of gold and silver is called نُزَهَة الْعَيْنَيْنِ فِي زَكَاِِ الْمَعْدِنَيْنِ the efficacy and privilege of the pleasant reading of his book. The same applies for a work on sexual themes and pornography by Shihāb al-Dīn Ahmad al-Tīfāshī, named نُزْهَةُ الَْأَبْبَابِ فِيمَا لَا يُوجَدُ فِي الْكِتَابِ On the other hand, al-Hubūr wa-l-surür fì wasf al-kbumūr, which was written by al-Nawājī (d. 859/1455) and was subject to severe criticism due to the vulgar love poetry and obscene materials in its content but was supported by art patronage and eventually became a highly demanded work, brings together the words pleasure/joy and drink in its title. When the denomination caused a reaction, the author, by elusion, had to change the name of his work to Halbat alKumayt.

In addition, the concept of "beauty" comes to the forefront as another emotional term with positive connotations. Numerous concepts with roughly the same meaning, such as "beauty (حُسنسن)," "the

10 Some examples include the following:

Kamāl al-Dīn al-Anbārī (d. 577/1181)

Yahyá ibn Ḥusayn al-Ṣancānī (d. 1099/1687)

Jamāl al-Dīn al-Wațwaṭ (d. 718/1318)

al-Tijānīi (d. 718/1318)

al-Kāfiyajī (d. 879/1474)

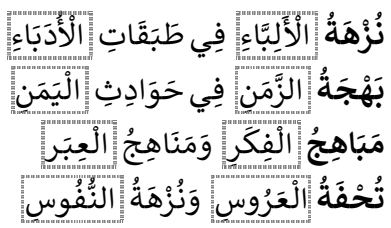

Zayn al-Dīn al-'Irāqīi (d. 806/1404)

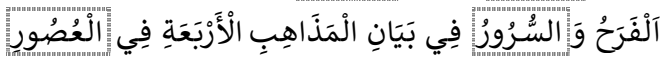

Other examples include the following:

Al-Malik al-Ashraf al-Rasūlī (d. 696/1296)

Al-Muțahhar ibn Ṭāhir al-Maqdis̄̄ (d. 381/991)

Ibn Aranbughā al-Zardakāsh (d. 867/1463)

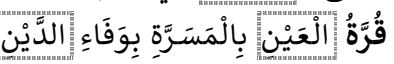

Zayn al-Dīn al-Khațīb (d.?)

Ibn Zafar al-Ṣiqillì (d. 565/1170)

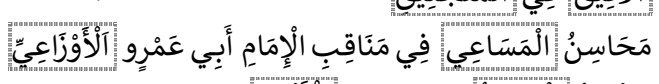

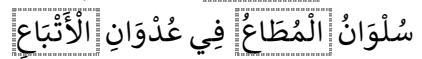


most beautiful (أَحْسَن)," "beauties (مَحَاسِن)," "comeliness (مَاََنَ)," and "handsome (أَنِيقن)," have been used to render more aesthetic hundreds of book titles. On the other hand, there are a significant number of consoling expressions, such as "سُلْوَان" "سُلْوَة".

"Water" as the source of abundance is another concept with positive connotations employed by Muslim authors in book titles. Nourished by teachings of the Islamic revelation that descended in the Hejaz Desert, Muslim nations attached particular importance to water in their civilizations as the main source of life. Indeed, a Qur’ān verse declared the universal rule that "water is the source of life." ${ }^{12}$ In addition, depictions of Heaven often pointed out rivers as the primary feature of paradise. One of the shortest sūrahs in the Qur'ān was named كَوَْثَ provided a pragmatic theme for Muslims to highlight the importance of their work since they longed for Adam's wine in their desert region. Accordingly, it is not surprising to see in the titles of hundreds

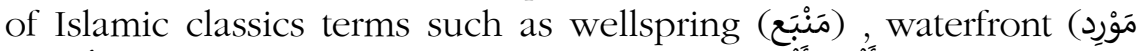

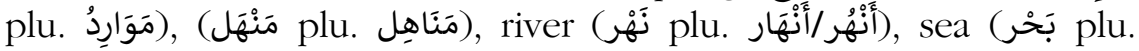

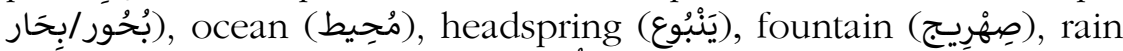

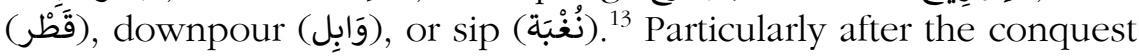
of al-Andalus, Muslims came across new fauna and flora that paved the way for the conceptual enrichment of book titles in parallel with floral and hunting themes in the literature. Accordingly, such themes came to the forefront in the titles of works by Andalusian scholars.

12 Q 21:30.

13 For examples, see

Ibn 'Ajībah (d. 1224/1829)

Ibn 'Allān (d. 1057/1648)

Shaykhzādah (d. 1078/1667)

Ibn al-Majdī (d. 827/1424)

Al-Haythamī (d. 807/1405)

Al-Bulqīnī (d. 805/1403)

Al-Fīrūzābādī (d. 817/1415)

Ibn Qayyim al-Jawziyyah (d. 751/ 1350)

Kamāl al-Dīn al-Khwārazmī (d. 836/1453)

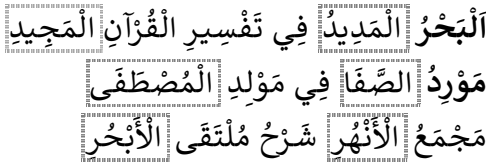

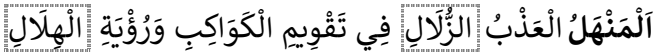

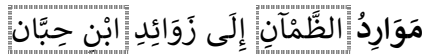

قَطْرُ السَّيْلِ فِي أَمْرِ الَْخَيْلِ

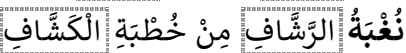

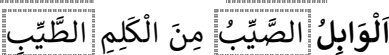

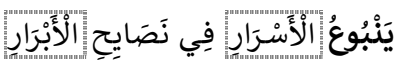


Evidently, Muslim authors, who decorated book titles with varying amounts and forms of water, were also interested in secondary concepts associated with it. Consequently, the titles of countless works include natural and pastoral concepts from Arabian and European flora. ${ }^{14}$ One of the most common natural themes is the

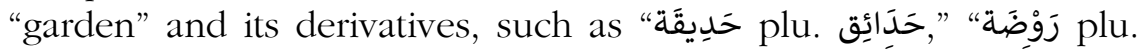

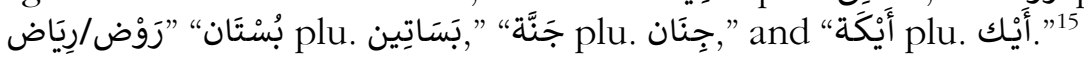

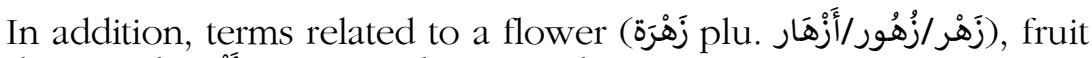

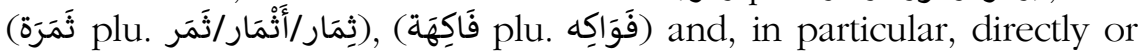

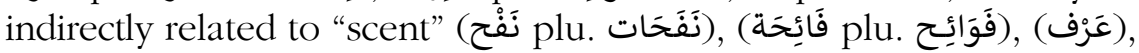

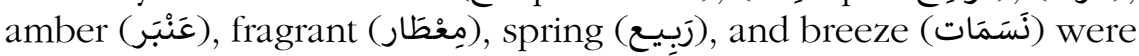
also in use because they were sine qua non elements of the same theme. ${ }^{16}$

14 Gustave E. von Grunebaum conducts a comprehensive examination of prose examples reflecting the admiration among medieval Muslim intellectuals of nature in his paper called "The Response to Nature in Arabic Poetry." See Journal of Near Eastern Studies 4, no. 3 (1945), 137-151, https://doi.org/10.1086/370750.

15 For examples, see

'Umar ibn Khalaf al-Ṣiqillī (d. 501/1107)

Al-Shahrazūrī (d. 687/1288)

'Abd al-Bāsiṭ al-Malațī (d. 561/1166)

Al-Suyūṭī (d. 911/1505)

Al-Malībārī (d. 991/1583)

'Alīi ibn Muhammad al-Khāzin (d. 741/1341)

Al-Suyūṭī

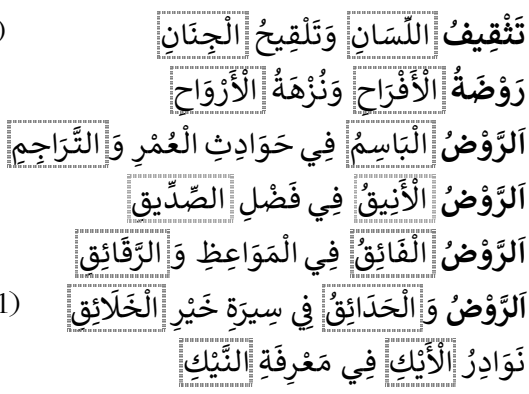

16 For some examples, see

Abū Isḥāq al-Huṣrī (d. 413/1022)

Al-Qasțallānī (d. 923/1517)

Ibn Sammāk al-'Āmilī ( $8^{\text {th }}$ century

$\mathrm{AH})$

Shihāb al-Dīn Aḥmad al-Tīfāshī

Al-Suyūṭī

Shihāb al-Dīn al-Khafājīi (d. 1069/1659)

Aḥmad al-Maqqarī (d. 1041/1632)

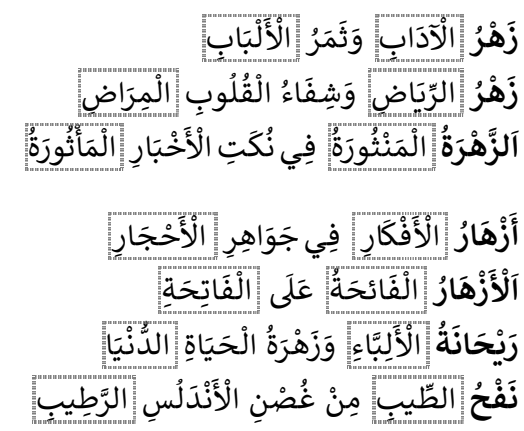


The concepts of "brightness and light" represented truth, justice, faith, and wisdom against "darkness," which symbolized untruth, persecution, blasphemy, and ignorance. Accordingly, these concepts became attractive elements for Muslim scholars who bore the responsibility of a mission to appropriate the communication of justice and truth. Consequently, book titles frequently applied terms that evoke the meaning of brightness and radiance. In this regard,

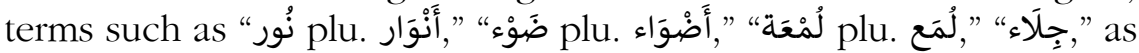

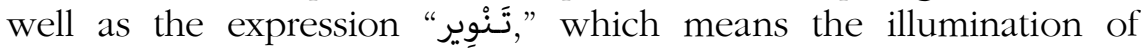
darkness, are used in the titles of books not only with Sufi content but also in almost any discipline. ${ }^{17}$

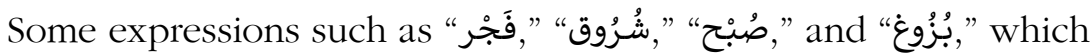
mark the beginning of the day or daylight, or even different time spans in proportion to brightness seem functional. For instance, when al-Qalqashandī (d. 821/1418) named his famous work on essential themes of literary composition, he likened the followers of this path to a person who walks in twilight and therefore cannot see well, and expressed the contribution of his work for such a person as

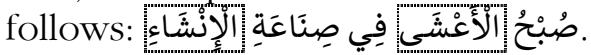

'Abd al-Raḥmān ibn Muḥammad al-Bisțāmī

al-Hurūfī (d. 858/1454)

Al-Suyūțī

'Alī al-Ṭabarī (d. 1070/1660)

Ibn 'Abd al-Mun'im al-Himyarī (d. 727/1327)

Al-Zamakhsharī (d. 538/1144)

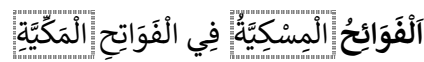

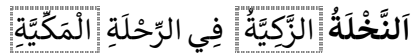

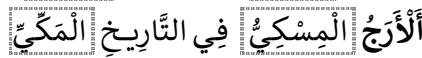

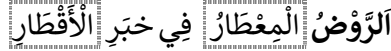

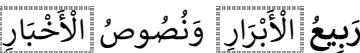

17 Some examples include

Al-Yaghmūrī (d. 673/1274)

Al-Dimnātī (d. 1306/1889)

Shihāb al-Dīn al-Qarāfī (d. 684/1285)

Al-Sakhāwī (d. 902/1497)

Al-Juwaynī (d. 478/1085)

Abū l-Hasan al-Ash'arī (d. 324/936)

Ḥākim al-Jishumī (d. 494/1101)

Al-Suyūṭī

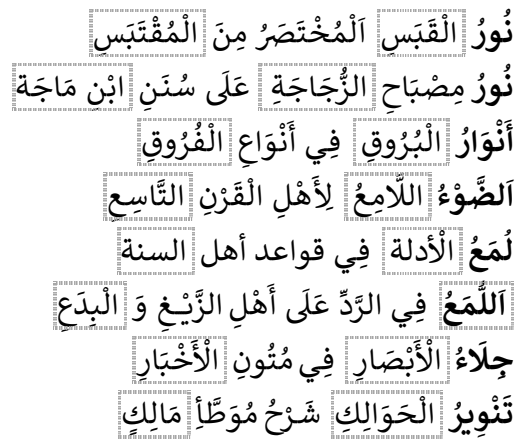


Many astronomical terms made an appearance in book titles,

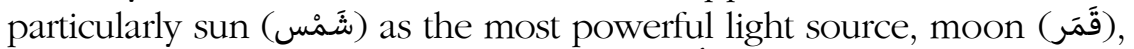

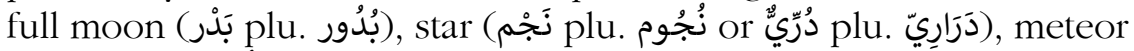

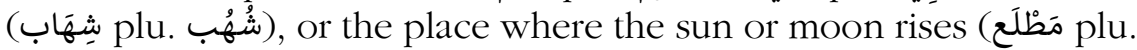

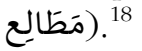

In addition, book titles comprised manmade instruments of

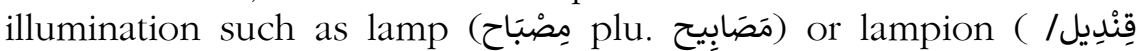
مِشْخَاة). For instance, the work by the famous Sufi 'Abd al-Qādir alJîlānī (d. 561/1166) on the holiness of Prophet Muhammad's ascension to heaven is named آلسِّرَاجُ الْوَهَّاجُ فِي لَيْلَة الْمِعْرَاجِ

In addition to the foregoing, a few concepts likely to arouse interest among disciples have served as a key in the creation of book titles. These expressions include the following terms with the same meter or pattern: "بُغْيَة" and "مُنْيَةَ" mean what is sought and desired by students of Islamic sciences; "غُنْنَّة" means what requires nothing further; and "بُلْغَة" means the very simple thing needed for life. In

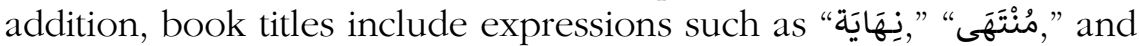
"غَايَّة," which refer to a certain goal and the summit to be attained. For instance, the versatile medieval Muslim scholar and physician Ibn alAkfānī (d. 749/1348) named his work on preventive medicine (اللبيبب عِنْدَ غَيْبَة الطَّبيب (Rich Information for Intelligent Men in the Absence of Physicians). Likewise, Quṭb al-Dīn al-Shīrāzī (d. 730/1330) claimed that his work signified the peak of astronomy at the time and

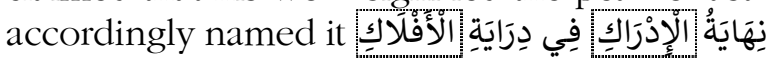

Some book titles, in turn, allowed for an assertive and even arrogant discourse by an author who claimed that the information therein was the ultimate knowledge attainable in the respective

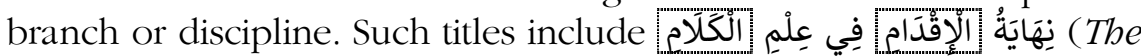

18 See, for example,

'Abd al-raḥmān ibn Muḥammad al-Bisțāmī

Jalāl al-Dīn al-Mahallī (d. 864/1459)

Al-Suyūțī

Ibn Jamā'ah (d. 819/1416)

Ibn al-Wardī (d. 749/1349)

Alā’ al-Dīn al-Ghazūlī (d. 815/1412)

Ibn al-'Adīm al-Halabī (d. 660/1262)

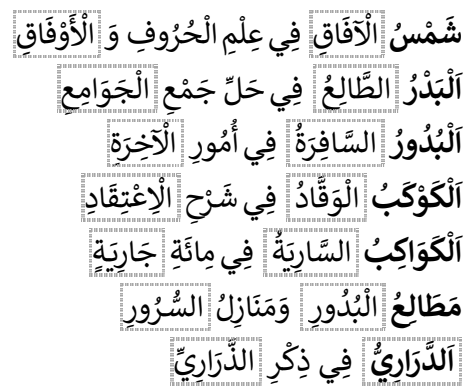


End of Steps in the Science of Theology) by the famous religious

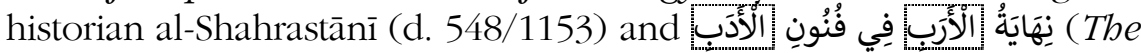
Ultimate Ambition in the Arts of Erudition), the 31-volume encyclopedia by the famous Mamluk historian al-Nuwayrī (d. 733/1333). ${ }^{19}$

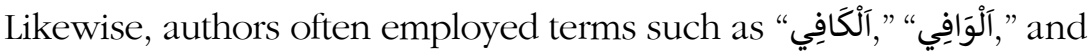
"كِفَايَة" to point out the sufficiency of a work in its respective discipline without the need for any other book:

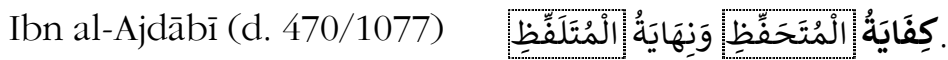

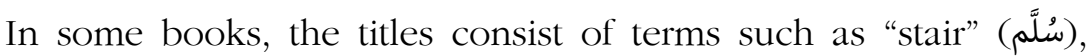

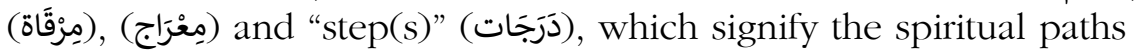

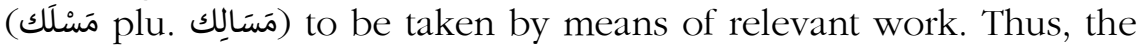
work is introduced to the reader as a means of attaining a distant or high objective. For example, the famous work by Ibn Hishām alNahwī (d. 672/1274) is named as below:

\section{أَوْضَحُ الْمَسَالِكِ إِلَى أَلْفِيَّة ابْنِ مَالِكٍ}

Such works are also considered a pathfinder, guide, assistant, savior, source of right guidance, or evidence, and they are named

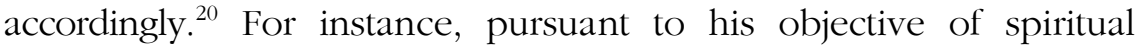

19 Some relevant examples include

Sayf al-Dīn al-Āmidī (d. 631/1233)

Kamāl al-Dīn al-Damīrī (d. 808/1405)

Sayf al-Dīn al-Āmidī

Al-Jammā’̄ilì (d. 600/1203)

Fakhr al-Dīn al-Rāzī (d. 606/1210)

Al-Ḍabbī (599/1203)

Ibn al-'Adīm (660/1262)

Abū 1-Ḥasan al-Qalṣādīi (d. 891/1486)

al-Maydānī (518/1124)

غَاَيةُ الْمَرَامِ فِي عِلْمِ الْكَلَامِ

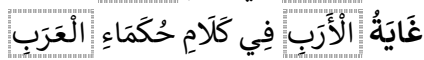

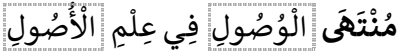

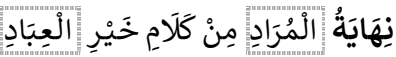

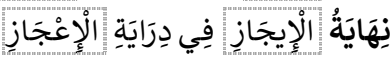

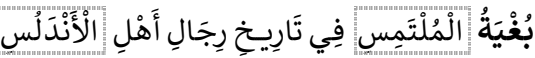
بُغْيَةُ الطَّلَبَ فِي تَارِيَِِ

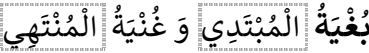

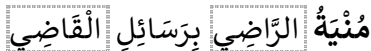

20 Some examples include

Al-Juwaynī (d. 478/1085)

Ṭāshkubrīzādah (d. 968/1561)

Ibn al-Mibrad (d. 909/1503)

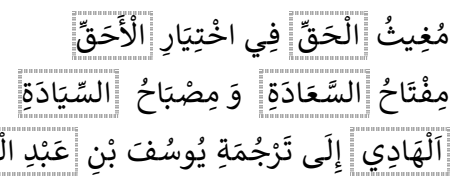


guidance for the reader, Ibn Qayyim al-Jawziyyah (d. 751/1350) named his work as follows:

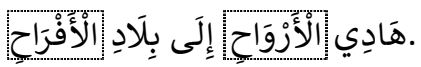

Some book titles benefit from other practical similes. In this context, some works are introduced as a kind of indispensable spiritual nourishment (غِذَاء) or sustenance (قُوت) (زَاد). For example, Ibn al-Jazzār (d. 369/979), the famous $4^{\text {th }}$-century pharmacist and physician, named his work, which was translated into Latin in a relatively earlier period thanks to its fame in the Muslim world, ${ }^{21}$ through an assimilation of indispensable practical knowledge in his book to the sustenance of travel or sustenance زَادُ الْمُسَافِِِ وَقُوتُ الْحَاضِِ In addition, a hadìth commentary by al-Suyūṭi attained successful harmony between the relevant theme and the name of the author: ق قُوتُ الْمُغْتَذِي عَلَى صَحِيحِ التِّرِِِْي

A group of book titles claim that truths unknown to most are explored by the author. Indeed, such titles may ensure interest in a certain work among readers. Presumably, the following title stimulates remarkable motivation for those who want to know more about the views of Ibn Qayyim al-Jawziyyah about the whirling ritual and music: ${ }^{22}$

$$
\text { كَشْفُ الْغِطَاعِ عَنْ حُكْمِ سَمَاعِ الْْغنَاءِ }
$$

(Unveiling of the Rules on Listening Songs)

We may note the use of expressions with sexual content in book titles. They mostly echo the male perspective and reflect lust,

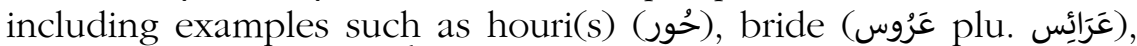

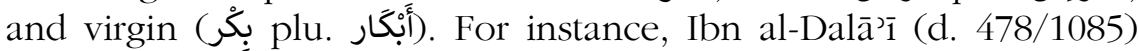
compiled some hadiths that constituted the basis for jurisprudent

al-Yumn al-'Ulaymī (d. 928/1522)

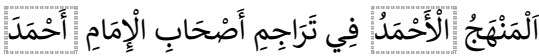

21 Khayr al-Dīn al-Ziriklī, al-A ‘ām: Qāmūs tarājim li-ashbar al-rijāl wa-l-nisàa' min al-'Arab wa-l-musta'rabin wa-l-mustashriqinn, 15 ${ }^{\text {th }}$ ed. (Beirut: Dār al-'Ilm li-1Malāyīn, 2002), I, 85.

22 Other examples include

Al-Sha'rānī (d. 973/1565)

Abū l-Hasan al-Qalṣādī (d. 891/1486)

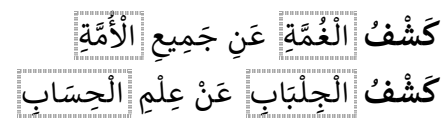


provisions as early as the lifetime of Prophet Muhammad and named his compilation as follows, hinting that it was the first of its kind:

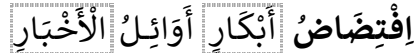 \\ (Defloration of Virgins, The Firsts of Narrations)}

The prolific $15^{\text {th }}$-century author al-Suyūți crowned the title of his annotation about Anwār al-tanzīl, the renowned tafsīr by alBayḍāwī, with a name pleasing to male lust:

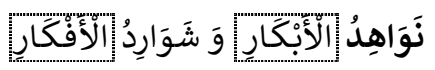

\section{(Virgins with Recently Blossomed Nipples [and] Overlooked Ideas)}

In fact, we encounter elements with sexual connotations in a semi-

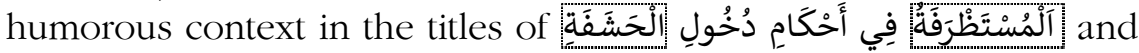
some other works by al-Suyūțî. ${ }^{23}$

Another smart move by Muslim intellectuals to enhance the popularity of a work was to refer to Qur'ānic terminology, making use of its profound influence on the spiritual world of readers. ${ }^{24}$ Accordingly, many classical and modern works skillfully incorporated certain concepts from holy scripture in their titles. For instance, the name chosen by the Arab linguist al-Muhibbī (d. 1111/1699) for his work about duals is inspired by the Qurān: الْمُثَنََّيْينِن.

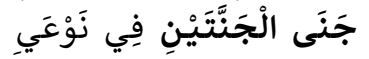

In a similar manner, 'Abd Allāh ibn 'Alī Ibn al-Wazīr al-Șan'ānī (d. 1147/1735) employs a clause completely identified with the Qur'ān in his work about a certain period in the history of Yemen: وَبَقُ الْحَحْلْوَى وَصِحَافُ الْمَنِْ وَالسَّلْوَى.

23 Other examples include

Al-Tha'labī (d. 427/1035)

Shams al-Dīn al-Āmulī (d. 753/1352)

عَرَائسنُ الْمَجَالِس

Al-Dawwānī (d. 908/1502)

Qāẹī Burhān al-Dīn (d. 870/1466)

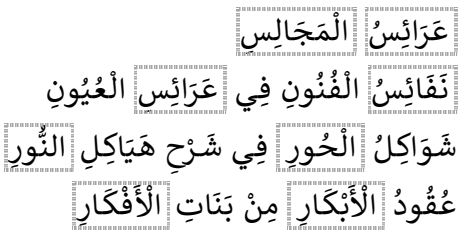

Von Grunebaum gives a comprehensive evaluation of the stimulating influence of Islamic religious motives on literature in general and on poetry in particular. See "The Spirit of Islam as Shown in Its Literature," Studia Islamica 1 (1953), 101119, https://doi.org/10.2307/1595011. 
Finally, it is worth noting that the thematic restriction, self-imposed by authors in naming their works, as seen in the foregoing examples, has occasionally led to certain confusions. Authors from different periods or different disciplines have sometimes chosen very similar and even identical names for their respective works. For instance, the same name is shared by a work of the $5^{\text {th }}$-century author Kamāl al-Din al-Anbārī (d. 577/1181) on grammar and a book by the $11^{\text {th }}$-century author Abū l-Qāsim al-Samarqandī (d. after 888/1483) on metaphor as a term of rhetoric: فَرَائِدُ الْفَوَائِد . Likewise, the paths of Hasan ibn Bishr al-Āmidī (d. 371/981) and al-Dāraquṭnī (d. 385/995) intersect in the names of their works: آلْمُؤتَلَفِفُ وَالْمُخْتَلِفِ

Most likely because of this defect, authors added distinctive expressions to the similar beginning of titles. An example can be seen below, showing one classical and one modern work:

Al-Maqqarī (d. 759/1358)

Ma'rūf al-Rușāfī (1875-1945)

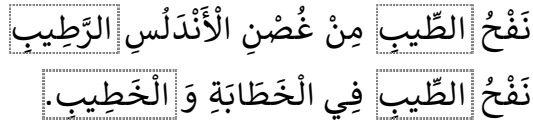

Therefore, the mere mention of book titles may not be sufficient in academic references; the name of the author should also be indicated on some occasions to prevent confusion.

\section{Strong Language of Refutations or Military Terminology in Book Titles}

The severity of criticisms within the content of a work is successfully reflected by their authors in book titles inspired by a rhetoric peculiar to military language. In this respect, book titles have, in a sense, served as a platform of defiance and the settling of accounts between authors from different madhhabs and backgrounds in public. The titles of many classical works are, so to speak, an area where scientific authorities square accounts with one another or seek prestige. The title of a work by al-Suyūṭī in response to criticisms against Abū Hanifah (d. 150/767) by the famous historian and hadith scholar al-Khațīb al-Baghdādī (d. 463/1071) is a clear example of such a denomination: آلسَُّْْمُ الْمُصِيبُ فِي نَحْرِ الْخَطِيبِ (Arrow Aiming at Chest of al-Khațīb [al-Baghdādī]). Likewise, the Hanafī jurist Ibn alDayrī (d. 867/1463) aims at the chest of apostates in the title of his work: آلسِّهَامُ الْمَارِقَةُ فِي كَبِدِ الزَّنَادِقَةِ (Outlaw Arrows Stuck in the Heart of Apostates). 
In addition to "arrow," "sword" is another much-referenced military weapon, including all its types and qualities. For instance, Ibn Taymiyyah (d. 728/1328) gives the following name essentially about "punishment for insulting Allah, prophets, and companions" but also punishment for disunion, blasphemy, the violation of agreements by آلَصَّارِمُ الْمَسْلُولُ عَلَى شَاتِمِمِ الرَّسُولِ (Unsheathed Sharp Sword against Insulters of Prophet). In a similar manner, the biographer Taqī al-Dīn ibn 'Abd al-Qādir alTamìmī (d. 1010/1601) named his work (which is no longer available) about his scapegrace son Hasan as آلسَّيْفِ الْبَرَّاقُ فِي عُنْقِ الْوَلَدِ الْعَاقِّ (Shiny Sword on the Neck of Rebel Son), implying his rage and fury. Quṭb alDīn al-Bakrī (d. 1162/1749), a relatively later author, named his work

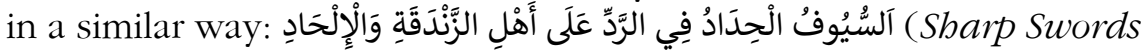
in Response to Apostates). In another later work, Ibn 'Usfūr al-Bahrānī (d. 1186/1772) writes a refutation by hinting at the title of Sharb Nabj al-balāghah of Ibn Abī 1-Hadīd (d. 656/1258) and calls it فَلَسِلُ الْحَدِيدِ فِي تَقْيِيد ابْنِ أَبِي الْحَدِيد (Putting Ibn Abi l-Hadìd in Iron Chains), to which Muhammad Amīn al-Suwaydī (d. 1246/1831) replies in a similar style: آلصَّارِمُ الْحَدِيدُ فِي عُنُقِ صَاحِبِ سَالَسِلُ الْحَدِيدِ (Iron Sword Hanging on the Neck of the Author of "Iron Chains").

The terminology becomes even harsher, employing natural elements instead of military tools in times of heated rivalry between faiths, ideas, or madhhabs. For instance, Ibn Hajar al-Haytamī (d. 974/ 1567) puts his foe to "burning thunderbolts" in the title الْمُحْرَقَةُ عَلَى أَهْلِ الرَّفْضِ وَالزَّنْدَقَةِ (Thunderbolts Burning Refusers and Profanes). In refutation of al-Haytamī's work, Amīn al-Hulwānī (d. 1316/1898) tries to neutralize this attack by means of treacherous waters: آلسُّيُولُ الْمُغْرَقَةُ عَلَى الصَّوَاعِقِ الْمُحْرِقَةِ (Floods to Drown Burning Thunderbolts). In modern times, a work for the refutation of Ridā Khān Biralwī (d. 1921) makes the respondent an aim of burning آلَّّهَابُ الثَّاقِبُ عَلَى الْمُسْتَرِقِ الْكَاذِبِ.

In some titles, interest is aroused through partially humorous touches. For instance, when Ibn Dihyah al-Kalbī (d. 633/1235) wrote الكَّارِمُ الْهنْدِيُّ فِي الرَّدِّ علَى الْكِنْدِيِّ in criticism of Abū 1-Yumn al-Kindì (d. 613/1217), he received a humiliating rejection in return:

\section{نَتْفُ اللَّحْيَةِ مِنِ ابْنِ دِحْيَة (Tearing the Hair of Ibn Dibyah)}

A similar approach is observed in the famous tract by Ibn alMuraḥhal (d. 699/1300), the poet and man of letters from Malaga, in 
response to criticisms against him: آلرَّْميُ لبالْحَصَى وَالضَّرْبُ بالْعَصَا (With Stones and Sticks).

In his work in response to allegations by a scholar who was a Muslim before converting to Christianity, al-Māzarī (d. 536/1141)

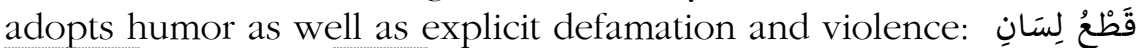
النّابِح فِي الْمُتَرْجَمِ بِالْوَاضِح (To Tear off the Tongue of Who Barks in Response to Eloquence).

Evidently, such defiance in book titles not only consolidated the respective community or fanatical followers of authors but also established a strong motivation to attract curious intellectual minds.

In addition to military terminology, critical or refutation works employed some libelous expressions that may damage the pride of readers as well as those with elements of violence. The two following examples, each written in defense of Muhyī al-Dīn Ibn al-'Arabī (d. 638/1240), may clarify our point:

Al-Suyūțī

Al-Biqā̄̄ì (d. 885/1480)

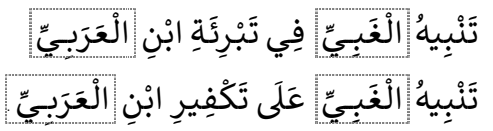

\section{Techniques}

There are certain criticisms and allegations that early Muslim intellectuals were interested in form rather than content and that therefore ornate prose and the saj' style are insufficient for the appropriate expression of the meaning. However, the objective of this paper is not to respond to such allegations or to show the evolution of the Arab style depending on eras. Instead, in this chapter, we will dwell upon positive examples of the extent to which certain book titles reflect the content. Indeed, Muslim authors have displayed extraordinary attention in determining the title of a work and have yielded appropriate book titles neither more nor less than required despite limitations due to $s a j^{c}$ and alliteration techniques. For instance, an explanatory tract about the nuance between bribery and a gift includes outright "clarity" in rhetorical terms: تَحْقِقُ الْقَضِيَّة فِي الْفَرْقِ بَيْنَ الرِّشْوة وَ[الْهَدِيَّة

A similar situation is observable in the laconic title of the sorrowful work by al-Maqrīzī (d. 845/1442) on scarcity and famine in Egypt

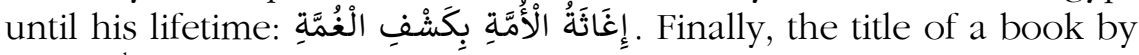
the $18^{\text {th }}$-century Azhar shaykh al-Damanhūrī (d. 1192/1778) about 
hemorrhoids involves explicit clarity: وَالْكَلَامُ الْيَسِيرُ فِي عِلَاجِ الْمَقْعَدَةِ وَالْبَوَاسِيِِ.

The following section of our study identifies certain techniques used in book titles that we find interesting in terms of form and theme. We provide relevant explanations after classifying them under certain categories.

\section{A. Rhymed Book Titles of Two, Four, or Six Words}

Muslim authors apparently did not exclude aesthetic elements such as meter, pun, and $s a j^{c}$ even in the formation of remarkably short titles that consist of two words. Indeed, hundreds of classical works are designed in a very concise manner since this style ensures significant advantages in pronunciation and memorability.

Some of the two-word book titles with saj are possessive constructions. One of the earliest examples is أَحَاسِنُ الْمَحَاسِن by Abū

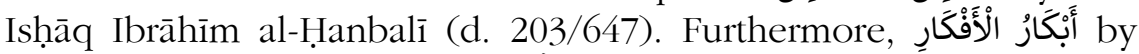
Sayf al-Dīn al-Āmidī and عَوَارِفُ الْمَعَارِفِ by al-Suhrawardī consist of

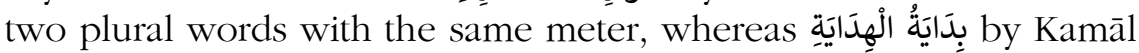
al-Dīn al-Anbārī and تَحْرِيرُ التَّحْبِيِِ by Ibn Abī l-Iṣbac (d. 654/1256) consist of two singular concepts with the same meter. ${ }^{25}$

Some of the two-word titles are in conjunctive form and connected to one another with the letter 9 . Plural examples with the same meter

25 For other examples, see

Sayf al-Dīn al-Dihlawī (d. 1052/1642)

أَخْبَارُ الَْخَخْيَارِ

Ibn Abī l-Shukr (d. 682/1283)

'Alī ibn Z̄āfir (d. 613/1216)

Salāḥ al-Dīn Khalīl al-Ṣafadī (d. 764/1363)

Sayf al-Dīn al-Āmidī

Sayf al-Dīn al-Āmidī

Taqī al-Dīn al-Maqrīzī

Kamāl al-Dīn al-Anbārī

Al-As'ad ibn Mammātī (d. 606/1209)

Fakhr al-Dīn 'Alī Ṣāfî (d. 939/1532-33)

'Alī ibn Muḥammad al-Khāzin

Athīr al-Dīn al-Abharī (d. 663/1265)
أَدَوَارُ الْأَنْوَارِ

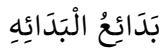

جِنَانُ الْجِنَاسِ

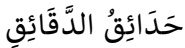

رُمُوزُ الْكُنُوِْ

سُلُوكُ الْمُلْوَك

فَرَائِدُ الْفَوَائِدِ

قَوَانِينُ الدَّوَاوِِينِ

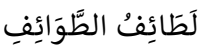

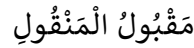

مَرَاصِدُ الْمَقَاصِدِ 


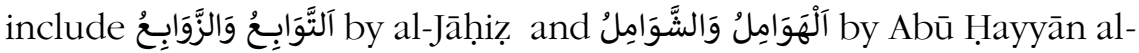
Tawhìiī (d. 414/1023), whereas singular examples with the same meter include آلْإِيجَازُ وَالْإِعْجَازْ by Abū Manșūr al-Thacālibī (d. 429/1038) and آلْبِدَايَةُ وَالنِّهَايَةُ by Ibn Kathīr (d. 774/1373). ${ }^{26}$

In addition to the two foregoing categories, there are rhymed book titles of two words with prepositions. Pursuant to our

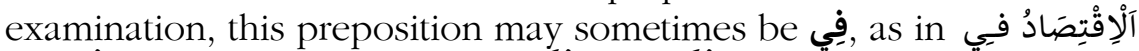

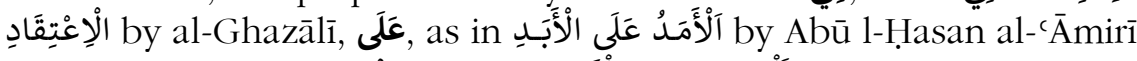

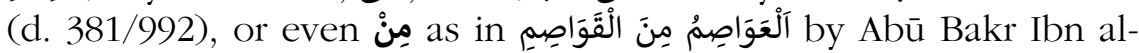
'Arabī (d. 543/1148). ${ }^{27}$

In punned noun phrases that consist of four words and are connected to one another with a conjunction, the determinatum is associated with the determinatum and the determinant is associated with determinant; in addition, there is an effort to establish a parallelism based on phonetic assimilation between equivalents in regard to adjective clauses. For better comprehension of the relation between words, we highlight the relation between elements in the first example below:

Ibn Abī l-Khiṣāl (d. 540/1146)

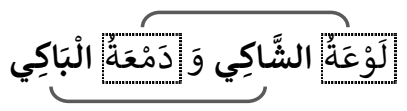

26 For other examples, see

Hamzah ibn 'Alī (d. 411/1012)

Muhammad al-Tamīmī al-Dārimī (d. 378/989)

Abū Ḥayyān al-Tawhịīī

Al-Suyūṭī

Al-Shahīd al-awwal (d. 786/1384)

$$
\begin{aligned}
& \text { آَإِعْذَارُ وَ الْإِنْذَارُ }
\end{aligned}
$$

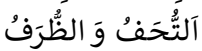

$$
\begin{aligned}
& \text { آلْبَصَائرُ وَ الذَّخَائُرُ } \\
& \text { اَلْمُحَاضَرَاتُ وَ الْمُحَاوَرَاتُ الُِْ } \\
& \text { آلْقَوَائِدُ وَ الْفَوَائِدِ } \\
& \text { آلََََّّائِدُ عَلَى الْفَوَائِدِ }
\end{aligned}
$$

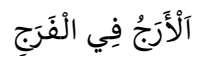

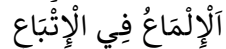

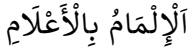

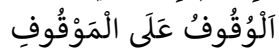

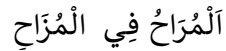

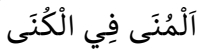

$$
\begin{aligned}
& \text { آلنّّهَايَةُ فِي الْكِنَايَةِ }
\end{aligned}
$$

Also see the following examples:

Najm al-Dīn al-Ṭarsūsī (d. 758/1357)$$
\text { Al-Suyūṭī }
$$

Ibn Fāris (d. 395/1004)

Qāsim al-Nuwayrī (d. 733/1333)

'Umar ibn Badr al-Mawșilī (d. 622/1225)

Badr al-Dīn al-Ghazzī (d. 984/1577)

Al-Suyūṭī

Abū Manșūr al-Thacālibī 
Șalāḥ al-Dīn Khalīl al-Ṣafadī (d. 764/1363)

Ibn Abī l-Khiṣāl al-Ghāfiqī (d. 540/1146)

Taqī al-Dīn Ibn Fahd (d. 871/1476)

Ismāc̄il ibn Ibrāhīm al-Mārdīnī (d.629/1232)

Abū Manșūr al-Tha'ālibī

Zakariyyā al-Qazwīnī (d. 682/ 1283)

Ibn al-Naqīb (d. 769/1368)

Raḍī al-Dīn Ibn al-Hanbalī (d. 971/1563)

Al-Nawājī

Ibn al-Azraq al-Gharnāṭī (d. 896/1491)

Shihāb al-Dīn al-Qarāfī

Tāj al-Dīn al-Subkī (d. 771/1370)

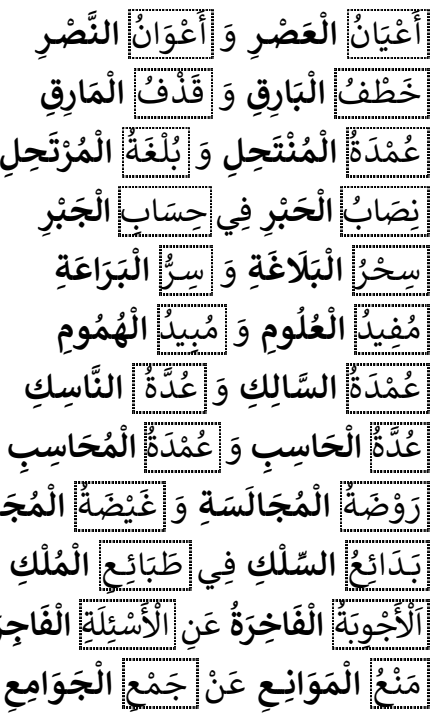

Punned book titles of six words literally recall an equation. The title is divided in two in the middle by means of a conjunction, leaving three words on each side in a symmetrical manner. Some examples are as follows:

al-Nahrawānī (d. 387/997)

آلْجَلِيسن الصَّالِحُ الْكَافِي وَ الْأنِيسُ النَّاصِحُ الشَّافِي

Ibn Hudhayl al-Fazārī al-

Andalusī ( $8^{\text {th }}$ century $\mathrm{AH} / 14^{\text {th }}$

عَيْنُ الْأَدَبِ وَالسِّيَاسَةِ وَ زَيْنُ الْحَسَبِ وَالرَِِّاسَةِ

century AD)

Ibn Hudhayl al-Fazārī

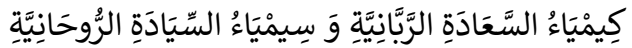

In both prose and verse, the most superior implementation of the art of muqābalah (comparison and collation) is to create a harmony in contradiction between more than two opposites. ${ }^{28}$ Muslim authors have yielded the most meticulous examples of this craft and created phrases that establish reciprocal relations between opposite elements

28 Abū 'Alī al-Hasan ibn Rashīq al-Azdī al-Qayrawānī, al-'Umdah fì mahāsin alshicr wa-ādābihī wa-naqdihī, ed. Muḥammad Muḥyī al-Dīn 'Abd al-Hamīd, $5^{\text {th }}$ ed. (Beirut: Dār al-Jīl, 1981), II, 15. 
in book titles of both four and six terms, as seen in the following examples:

'Azīz Maḥmūd Hudā'̄̄ (d. 1038/1628)

جَامِعُ الْفَضَائِلِ وَ قَامِعُ الرَّذائِلِ

Al-Qarabāghī (d. 942/1535)

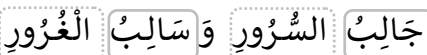

Al-Wațwāṭ (d.718/1318)

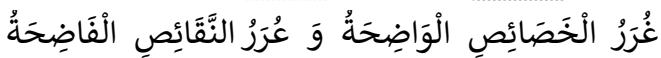

\section{B. Utilization of Arabic Plural Forms in the Creation of Puns}

Muslim authors mobilized all means of linguistics to create book titles that are pleasing to both the eye and the ear. In this respect, they often referred particularly to certain plural patterns. Thanks to their pronunciation and lyrical resonance that remain in the memory,

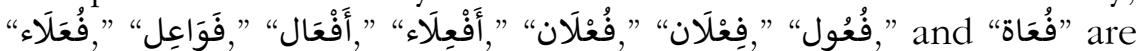

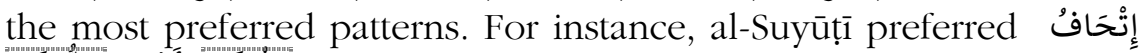
for his satirical tract about unlikeable typologies.

Likewise, "أَفْعَلَاء" is is used by Ibn al-Mițān al-Dimashqī (d.

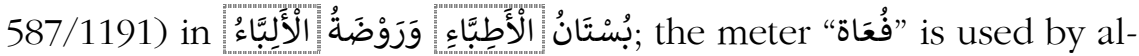

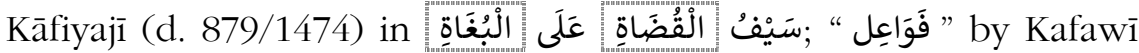

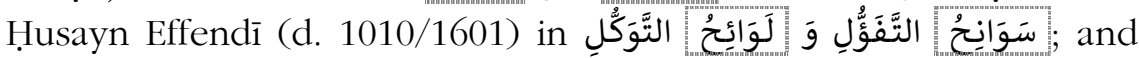

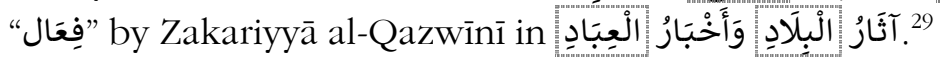

The foregoing list should be complemented with feminine plural forms as one of the most available patterns for puns:

Al-'Awfī (d. 629/1232)

جَوَامِعُ [الْحِكَايَاتِ وَلَوَامِحُ [الرِّوَايَاتِ

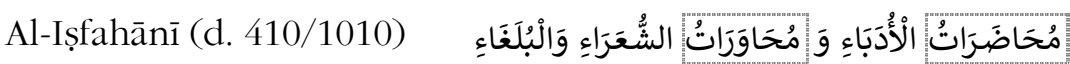

29 For other examples, see

Abū l-'Abbās al-Jurjānīi (d. 482/1089)

Abū Hạāmid al-Ghazālī (d. 505/1111)

Al-Jāḥiz

Ibn Iyās (d. 930/1524)

Anonymous

Al-Suyūṭī

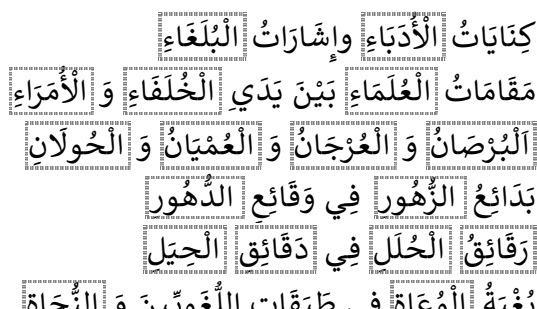


The authors, who had mastered syntax, were able to create astonishing combinations even in unforeseeable plural forms. In addition, some examples show that plurals in a certain meter coexist with other plurals that are similar in terms of form or pronunciation, albeit with different meters. Moreover, there are a significant number of examples in which a plural form skillfully creates a pun with a completely different, non-plural word:

Abū 1-Hajajāj al-Balawì (d. 604/1208)

Al-Khațīb al-'Uthmānī (d. 780/1378)

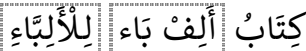

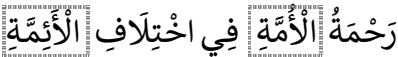

Another effective pun technique is the phonetic harmony established by a present participle derived from the same root and plural forms of words that rhyme with it, such as "noun of place" or "infinitive with mim." Old scholars invented striking titles in this respect. The artistry in the following examples becomes even more interesting when the chosen words are read by pausing on them:
Aḥmad ibn Muḥammad al-Ghaznawī (d. 593/1197)
عُدَّةُإلنَّاسِكِ فِي إلْمَنَاسِكِك
Mar'ī ibn Yūsuf al-Karmī (d. 1033/1624)

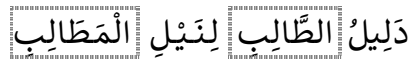
Ibn Abī l-Rabīc (d. 688/1289)

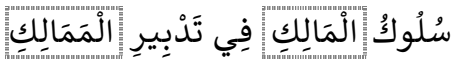
Ibn al-Akfānī

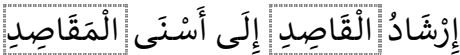
Taqī al-Dīn al-Jarrā̄̄ì

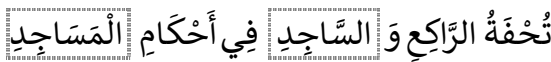

\section{Skillful Assembly of Nouns and Verbs in Puns}

Since the classical period, Muslim authors have invented interesting book titles where one part of the pun consists of a noun and the other is created by appropriate verbs. In this respect, the harmony between nouns and verbs is remarkable. For better perception of this harmony, the noun at the beginning and the verb at the end should be read without wovelizing their final letters (by a pause). For instance, the classic by al-Dhahabī (d. 748/1348) on history should be read as follows:

$$
\text { آلَعِبَر فِي خَبَبر مَنْ [غَبَر }
$$

al- Ibar fì khabar man ghabar

Some striking examples are given below: 
'Abd al-Salām Effendī al-Mārdīnī (d. 1843)

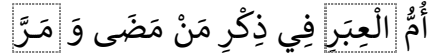

Ibn al-'Imād al-Hanbalī (d. 1089/1679)

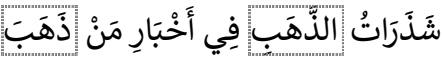

Ibn 'Aqïlah (d. 1150/1737)

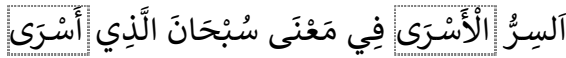

Taqī al-Dīn al-Subkī (d. 756/1355)

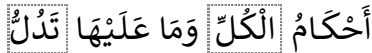

Al-Yumn al-'Ulaymī

Al-Kalā̄ì (d. 634/1237)

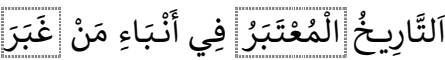

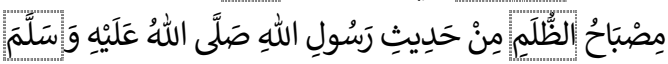

Thus, nouns and verbs are brought together to create puns. In addition, we encounter the interesting assimilation of a possessive conjunction with a pronoun and a noun without a pronoun. For example, the tract by al-Fīrūzābādī (d. 817/1415) about famous personalities whose names are ascribed to others than his father is

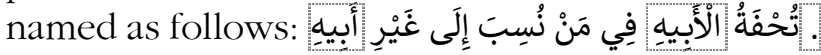

\section{Titles Based on Wordplay}

Because of the intense use of puns, some book titles recall tongue twisters and consist of alliterations that are relatively difficult to pronounce. Indeed, it is by no means easy to memorize these book titles, and pronunciation undergoes frequent tongue slips. This might be considered a joke by the author as well. For instance, Zayn al-Dīn al-'Irāqī (d. 806/1404), who wants to enlighten his contemporaries with the important information in Ibya ' 'ulūm al-din, names his work "إِخْبَارُ الْأَحْيَاءِ بَأَخْبَارِ الْإِحْيَاءِ ; likewise, 'Alā' al-Dawlah al-Simnānī (d. 736/1336) names his work on the virtues of "Alì ibn Abī Țālib

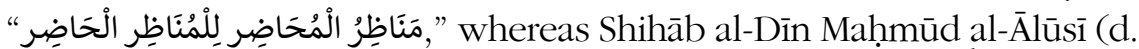

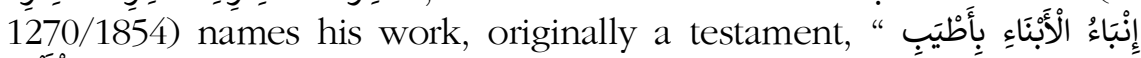
الأْنَبَاءع." Furthermore, the mathematician Ismā c̄il ibn Ibrāhīm al-Mārdīnī (d. 629/1232) designs his own elementary numbers as a kind of

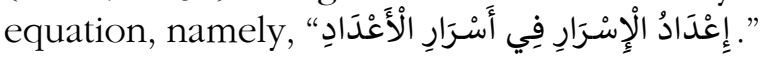

\section{Book Titles Formulized in Anagrams}

Scholars also opted for anagrams in which they reversed a given title or two terms therein or created a kind of riddle between words by reversing the letters in these terms to create parallel, contrasting, or associated combinations. For example, al-Suyūṭi establishes such a

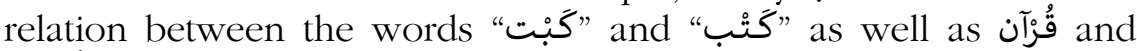
"أَقْرَان" in the title of his work that seeks to gather his contemporary 
scribes under a standard practice of Qur’ānic orthography: كَبْتُ الَْافَقرَانِ فِي كَتْبِ الْقُرَآنِ.

In a similar manner, when naming his book about the fire in Damascus in $740 \mathrm{AH}$, Ibn al-Wardi applies the technique of alteration

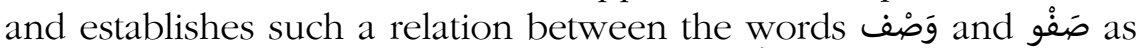
well as رَفْوُ الرَّحِيقِ فِي وَصْفِ الْحَرِيقِ : حَرِيق and رِيق

The qașidah anthology by the famous book seller and poet alHazīin (d. 568/1172), also known as the "book guide," is named in a لُمَحْ الْمُلحِح.

Below are some interesting book titles that are derived pursuant to the technique of an anagram, where a relation is established between two words by the interchange of the places of letters:

Ibn Khaldūn

Ibn al-Kirmān̄̄ (d. 833/1430)

Ibn al-Naqīb al-Mișrī (d. 769/1368)

Nizāàm al-Dīn al-Nīsābūrī (d. 730/1329)

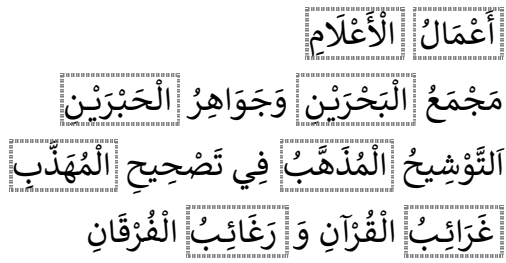

\section{Technique of Establishing Relationships between Dotted and} Non-Dotted Letters

Some wordplays in book titles establish relations between words that are formally identical but vary through dots. Such relations are often between analogous letter groups such as ص- ص $ض$. For example, the title of the famous biography of his contemporaries by Ibn Hajar al-'Asqalānī has such an aesthetic aspect:

$$
\text { إِنْبَاءُ الْغُمْرِ بِأَبْنَاءِ الْعْمْرِ. }
$$

Other examples are given below:

Ibn al-Athīr (d. 637/1239)

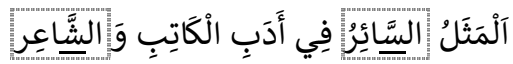

Al-Biqā̄i

Ibn al-Hāājib (d. 646/1249)

Ibn Yạ̣yá al-Wansharīsī (d. 914/1508)
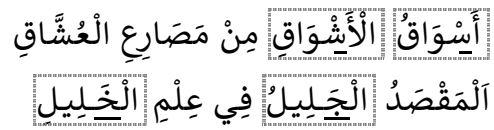

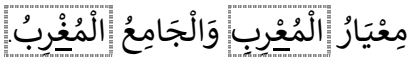




\section{Technique of Reading the Same Word with Different Vowels}

Vowels are a phenomenon in the Arabic language that allows diverse pronunciations of the same word. This characteristic has pushed classical Muslim authors to make use of this linguistic feature and to turn it into an artistic advantage. Consequently, authors have found a kind of pleasure in gathering together in their book titles analogous words that differ through one or more vowels despite consisting of the same letters. Thus, we have many classical works that can be pronounced in different manners with or without vowels; this method points out the subtle wit and fine anticipation of the author.

For instance, in his آلَمْشُرِقُ فِي حُحلى الْمَشْرِقِ, Ibn Sa'īd (d. 685/1286) employs a change of vowels in the letter mim, whereas shaddah is replaced in بَحْرُ الْعَوَامِ فِيمَا أَصَابَ فِيهِ الْعَوَامَ by Radī al-Dīn Ibn al-Hanbalī (d. 971/1563). The title of the following work by the Shâfici jurist Muhibb al-Dīn al-Ṭabarī (d. 694/1295) would be hard to read if the letter is not vowelized:

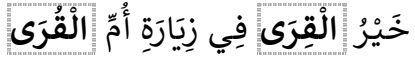

In this regard, some examples in which a kind of play is made with words and concepts are given below:

'Abd al-Qāhir al-Baghdādī (d. 429/1038)

Najm al-Dīn al-Nasafī (d. 537/1142)

As‘ad Effendì (d. 1166/1753)

Al-Suyūṭī (d. 911/1505)

Al-Ja'barī (d. 732/1332)

Ibn al-'Irāqī (d. 826/1423)

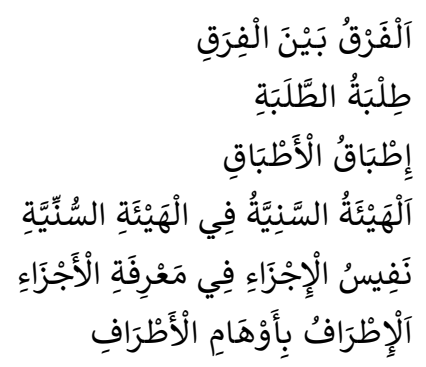

Another important category based on phones and timbers is ensuring matchup or identification by dropping or adding a letter. For example, Jamāl al-Khalwatī (d. 899/1494) makes use of the formal and vocal similarity between "حَبَّبَّةُ الْمَحَبَّةِ

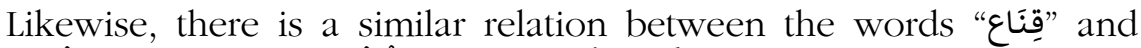

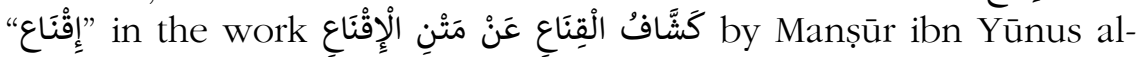
Buhūtī (d. 1051/1641). 


\section{Technique of Title Formation Based on the Pronunciation of Analogous Letters}

In some titles, authors opt for wordplay based on pronunciation by establishing a relationship between phonetically similar letters.

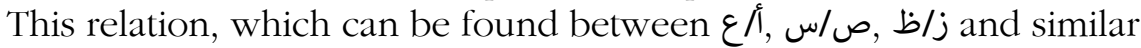
duos, comprises such artistry that it can only be understood through an attentive experience of pronunciation. For example,

\section{Al-Fīrūzābādī}

Ibn ‘Abd al-Zāhhir (d. 692/1293)

Ibn Sa ${ }^{\mathrm{i}} \mathrm{i}$ al-Maghribī

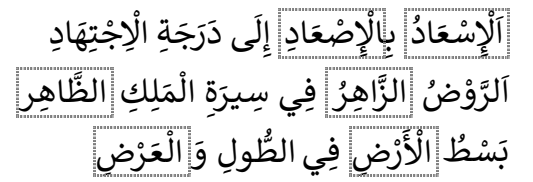

\section{Techniques of Dropping, Adding and Changing Letters}

Another particularly effective and successful implementation of saj ${ }^{c}$ is to bring together words, one shorter and one longer in pronunciation, within the same book title. More precisely, authors use this technique to create the shorter word by dropping some letters of the longer. For instance, the work by al-Suyūți in praise of a rooster is named آلَوَديكُ فِي فَضْلِ الدَّيكِ

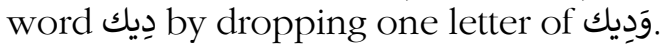

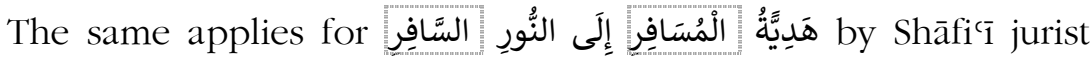
تَحْبِيرُ الْمُوَشَينَ فِيمَا يُقَالُ بِالسِّينِ وَالشَّين by al-Fīrūzābādī. The opposite examples are observable in the

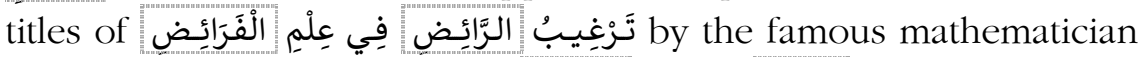

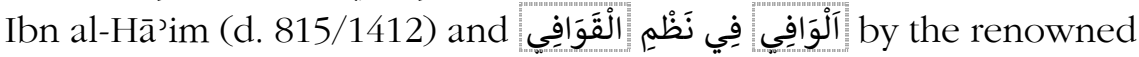
elegiac poet Abū l-Baqā’ al-Rundī (d. 684/1285).

Another common saj method is to use two words together that consist of an equal number of letters with a single different letter. For instance, Niz̄ām al-Dīn al-Nīsābūrī (d. 730/1329) named his annotation

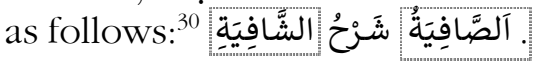

30 Other examples include

Muhỳì al-Dīn Ibn al-'Arabī

Al-Biqācī

Ṣalāḥ al-Dīn Khalīl al-Ṣafadī

شَقُّ الْجَيْبِ لِمِفْتَاح الْغَيْبِ

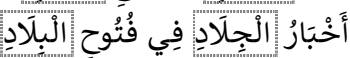

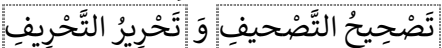




\section{E. Skillfully Created Titles with Puns in Compliance with Proper Nouns}

Proper nouns are another area of application where Muslim authors proved their creativity in the style of $\mathrm{saj}^{\mathrm{c}}$. In the titles of thousands of classical works, these nouns are matched with words that are phonetically appropriate and pleasing to the ear. By combining authors' language taste with their subtle wit, many foreign names are adapted to the meters and patterns of the Arabic language. In addition, there is no distinction regarding whether a name actually belongs to a person, place, or book. Successful examples are observable in a work by Najm al-Dīn al-Nasafī about scholars of Samarqand, where he uses the word "sugar" (قَنْد ) together with a place name (سَمَزَقَنْدن); in the work by Ibn 'Asākir (d. 600/1203) with

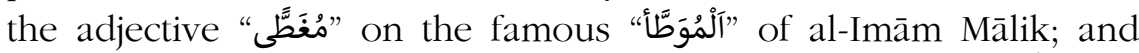
finally, between the word "فَاشُوش" and the proper noun "قَّرَاقُوش" in the political criticism by Ibn Mammātî, who wrote about the deeds of Bahā’ al-Dīn Qarāqūsh (d. 597/1201), the potent governor of Cairo in the time of Șalāh al-Dīn $(589 / 1193):^{31}$

Kamāl al-Dīn al-Fārisī (d. 716/1319)

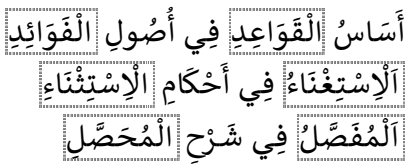

Shihāb al-Dīn al-Qarāfī

Al-Kātibī (d. 675/1277)

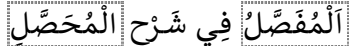

31 Other examples with prominent artistic aspects include

a) Person Names

'Abd al-Qāhir al-Baghdādī

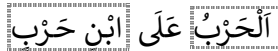

Abū Ṭālib al-Marwazī (d. 614/1217)

Ibn Țūlūn (d. 953/1546)

Ibn al-Mulaqqin (d. 804/1401)

Al-Bisāṭī (d. 842/1439)

Ibn 'Abd al-Hādī al-Maqdisīi (d. 744/1439)

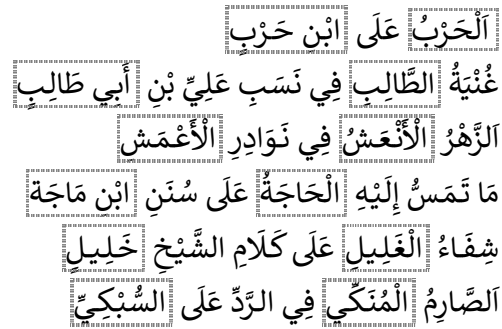

b) Place Names

Lisān al-Dīn Ibn al-Khațīb

Al-Sakhāwī

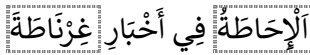

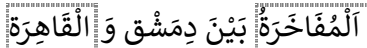




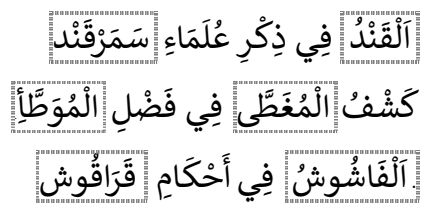

\section{Conclusion}

Rhymed prose, which Muslim authors could not help but employ in naming their works, is one of sui generis characteristics of Arabic linguistics. In fact, this practice based on phonetic aesthetics has become an artistic effort uncommon in other cultures but ever popular among Muslim authors.

It is fair to say that the works written during first two centuries $\mathrm{AH}$ do not include such ornamental endeavors or concerns. Nevertheless, particularly as of the early $3^{\text {rd }}$ century $\mathrm{AH}$, scholars have tried to generate titles with eloquent, compelling, and artistic wordings so that their intellectual crops and scientific studies are remembered in an easier manner. Consequently, the work by a scholar or man of letters attracted greater attention from intellectual circles and attained greater popularity among the public.

The embellishment of book titles by ornamental concerns can bring together a Mauritanian scholar, an Andalusian poet, a Basrian journalist or a Yemeni historian in a very specific field of language and in the same pot of pleasure.

The influence and pressure of the age-long tradition of composing thematic and lyrical book titles in the Muslim world is also observable in non-Arabic works. For instance, the same method has been followed for centuries in the Ottoman writing tradition; similarly,

Abū l-Ḥasan 'Alī al-Jaznā'̄ì (d. 766/1365)

زَهْرَةُ [الَآسسِ فِي بِنَاءِ مَدِينَةِ [فَاس

'Abd al-Raḥmān al-Dabbāgh (d. 699/1300)

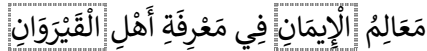

'Alī ibn Ḥasan al-Khazrajīi (d. 812/1410)

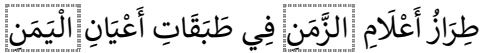

Ibn 'Asākir

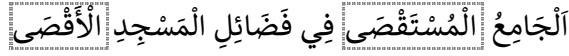


Iranian scholars, who wrote in Persian, could not stand idly by this tradition as they named their respective works.

The technique of making use of the power of $s a j$ is based on the humorous and artistic syntax of words in book titles. This technique still preserves its importance today, and modern authors continue to name their works with similar attention and sensitivity.

\section{DISCLOSURE STATEMENT}

No potential conflict of interest was reported by the author.

\section{BIBLIOGRAPHY}

Dayf, Shawqī. Tārìkh al-adab al-'Arabì. Cairo: Dār al-Ma'ārif, 1995. Vol. IV (al-'Așr al-'Abbāsī al-awwal).

Gutas, Dimitri. "Classical Arabic Wisdom Literature: Nature and Scope." Journal of the American Oriental Society 101, no. 1 (1981): 49-86. https://doi.org/10.2307/602164.

al-Jurjānī, Abū l-Ḥasan 'Alī ibn Muḥammad ibn 'Alī al-Sayyid al-Sharîf. Kitāb alta'rīfät. Edited by Ibrāhīm al-Abyārī. Beirut: Dār al-Kitāb al-'Arabī, 1985.

al-Kafawī, Abū 1-Baqā̄ Ayyūb ibn Mūsá al-Husaynī. Al-Kulliyyāt: Mucjam fì lmuștalahāt wa-l-furūq al-lughawiyyah. Edited by 'Adnān Darwīsh and Muhạmmad al-Mișrī. $2^{\text {nd }}$ ed. Beirut: Mu’assasat al-Risālah, 1998.

Kātib Chalabī, Ḥàjī Khalīfah Muștafá ibn 'Abd Allāh. Kashf al-zunūn 'an asāmī lkutub wa-l-funūn. 2 vols. Edited by M. Şerefeddin Yaltkaya and Kilisli Rifat Bilge. Baghdad: Maktabat al-Muthanná, 1941.

Murat, Mualla and Gizem Gülkanat. "Onomastik Bilimi ve Eğitim." Sosyal Bilimler Dergisi 5, no. 28 (2018): 247-256. http://dx.doi.org/10.16990/SOBIDER.4485.

al-Qalqashandī, Abū l-'Abbās Shihāb al-Dīn Aḥmad ibn 'Alī. Șuḅ̣ al-a'shá fì șinā'at al-insh $\bar{a}$ ? 14 vols. Edited by Muḥammad Ḥusayn Shams al-Dīn. Beirut: Dār alKutub al-'Ilmiyyah, 1987.

al-Qayrawānī, Abū 'Alī al-Ḥasan ibn Rashīq al-Azdī. al-'Umdah fì mahāsin al-shicr wa-ādābihì wa-naqdihī. Edited by Muḥammad Muhỵi al-Dīn 'Abd al-Hamīd. 2 vols. $5^{\text {th }}$ ed. Beirut: Dār al-jīl, 1981.

Stewart, Devin J. "Sajc in the Qur'ān: Prosody and Structure." Journal of Arabic Literature 21, no. 2 (1990): 101-139. https://doi.org/10.1163 /157006490X00017.

van Gelder, Geert Jan. Classical Arabic Literature: A Library of Arabic Literature Anthology. New York and London: New York University Press, 2013. 
"Antidotes and Anecdotes: A Literary History of Medicine from 13th-Century Syria." In Wit and Wisdom in Classical Arabic Literature: Leiden Lectures on Arabic Language and Culture, Petra M. Sijpesteijn, James A. Montgomery, and Geert Jan van Gelder. Leiden: Leiden Publications, 2015.

von Grunebaum, Gustave E. "The Response to Nature in Arabic Poetry." Journal of Near Eastern Studies 4, no. 3 (1945): 137-151. https://doi.org/10.1086 /370750.

_. "The Spirit of Islam as Shown in Its Literature." Studia Islamica 1 (1953): 101119. https://doi.org/10.2307/1595011.

al-Ziriklī, Khayr al-Dīn. al-A ‘ām: Qāmūs tarājim li-ashbar al-rijāl wa-l-nisā’ min al'Arab wa-l-musta'rabìn wa-l-mustashriqinn. 8 vols. $15^{\text {th }}$ ed. Beirut: Dār al-cilm li1-Malāyīn, 2002. 